日平滑筋誌（Jap. J. Smooth Muscle Res.） 16：297-305，1980.

\title{
イヌ大腸運動に関する研究
}

第 1 編 イヌ大腸運動の筋電図拈よび機械曲線による分析

\author{
徳島大学医学部 第一外科学教室 \\ (主任：古味信彦教授)
}

喜多 孝志

\section{MYOELECTRICAL AND MECHANICAL ACTIVITY OF DOG COLON}

\author{
Takashi KITA \\ First Department of Surgery, School of Medicine, \\ Tokushima University, Tokushima \\ (Director: Prof. N. Komi)
}

To study the movement of dog colon, bipolor electrodes and strain gauges were attached to the four different portions, ascending, transverse, descending and sigmoid colons.

Myoelectrical activities and mechanical activities were recorded simultaneously in the conscious state for one month.

Slow waves were recorded more clearly in the proximal colon than in the distal colon.

The frequencies of the slow waves were $5 \sim 6 \mathrm{cycles} / \mathrm{min}$ and were not altered by intravenous administration of motor stimulant agents. A spike activity complex was recorded more frequently in the distal colon than in the proximal colon. The spike activity complex usually appeared when contraction movement of the colon was active. The incidence of spike activity complex was mostly high in the descending colon. Contractile activity appeared once every minute with spike activity complex lasting for $10 \sim 30$ minutes.

On a low residual meal, mechanical activity and spike activity complex propagated from ascending colon to rectum were observed more distinctly than on usual dog food.

\section{I. は じ め に}

大腸は甪便の形成, 貯留, 輸送および排泄など の機能を有し，その運動形式の多様性が推定され る. 大腸は通常胃や小腸のように規則正しい運動 形式を示さずかつ運動が緩慢であることから, 生 体内で運動を観察し分析することは困難であると 考える（喜多ら，1978）。運動を観察する一方法 として電気生理学的な分析があるが, 生体内での 大腸運動を研究した報告は少なく, また筋電図学 的にも確立されたものがない. 生体内での植込み
電極法による慢性実験では, 大腸は基本的電気活 動の電位が低いため, 他の消化管の電気活動およ び運動などの影響をらけやすく，その解釈がさら に困難となっていると考えられる，そこで大腸運 動をさらに詳細に知る目的で正常雑犬を用いて, 双極電極および strain gauge を大腸壁に植込 み, 大腸筋電図と機峨曲線を同時に導出し, 大腸 運動の分析を行ない 2 3 の知見を得たので報告 する。 


\section{II. 実 験 方 法}

雑種成熟イヌ 15 頭を用いて以下の実験を行 なった．ラボナール（田辺製薬）静脈麻酔下に無 菌的に下腹部正中切開にて 開腹した。 5 頭には 4 コの 双極電極のみを植込み, 10 頭には 4 コの双 極電極と自家製作の防水型 strain gauge 2 コを大 腸の漿膜面に縫着した。電極は大腸を 4 分し, イ 又の上行結腸, 横行結腸, 下行結腸および直腸の 4 力所に, strain gauge は上行結腸と下行結腸の 部位に電極と対応させて縫着した。 strain gauge の軸は輪状筋の走行と平行になるよらに縫着した (図 1).

記録は術後 1 週間より開始し, 次のような条件 下に記録，分析を行なった。
1）空腹時
2）摂食時
3）排便時
4) 各種の薬剤投与時

運動促進剤： tetragastrin, prostaglandin $\mathrm{F}_{2 \alpha}$, vagostigmine

運動抑制剂： atropine

5） 24 時間の連続記録（週 2 回）

6）低残椬食（大塚製薬製ボンコロン）投与前 後

電気活動の記録には生体電気現象增巾器 (三栄 測器社製 EG402）およびポリグラフ（三栄測器社

\section{III. 実}

\section{A. 空腹時，摂食時，排便時の大腸筋電図}

空腹時には通常上行結腸から直腸に打沙る各導 出部位で各々異なった電気活動が記録され，近位 および遠位大腸に slow wave および多様な spike activity が不規則に出現した（図 2). slow wave の発生頻度は 5〜 6 cycles/min のものが多かった が, 12〜13 cycles/minの spike activity が不規 則に出現する時期もあった。 をた 5 ～6 cycles/ min と 17〜18 cycles/min の 2 種類。の spike activity が同時に出現する時期があるなど時間の 経過とともに spike activity の発生頻度に変化を 生じた. spike activity が連続して出現して一つ の集合した形をとる spike activity complex は 近位大腸にも遠位大腸にも出現したが，多くは遠 位大腸に出現した。排便時には，直腸に spike

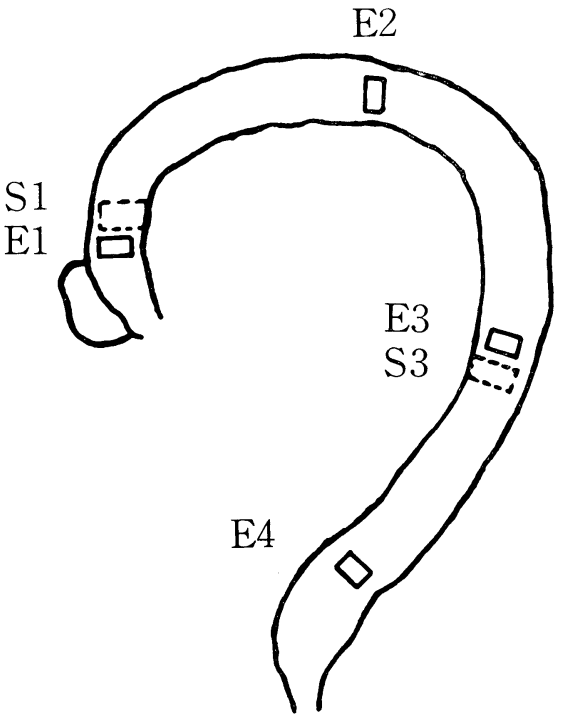

図 1.電極および strain gauge の装着部位

$\mathrm{E} 1, \mathrm{~S} 1$ ： 上行結腸

E2：横行結腸

E3, S3：下行結腸

$\mathrm{E} 4$ ：直腸

(Eは電極，Sは strain gauge を示す)

製 142-8）を用いた。筋電図は時定数 0.3 秒また は 0.03 秒で記録した。

\section{験 結 果}

activity complex が必ず出現し，排便後はこの 電位の振巾が時間を経るとともに減衰した，排便 時もやはり上行結腸から下行結腸ではそれぞれ異 なったパターンの電気活動を示した（図3). 空 腹時に導出された spike activity complex の持 続時間は $22.8 \pm 9.5$ 秒，休止時間は $28.8 \pm 11.7$ 秒で約 1 分間に 1 回出現した. この時の持続時間 は時間とともに变動し，5〜 7 分の 周期で 増減し た. 摄食後には spike activity complex は増強 し，持続時間は $35.3 \pm 10.9$ 秒，休止時間は 38.3 \pm 20.4 秒と延長した.

\section{B. 薬物刺激時の大腸筋電図}

slow wave $の$ 発生頻度は薬物投与前 5 分間, 投与開始直後 $~ 5$ 分, 投与開始後 25 30 分, 投 与終了後 25〜30 分について 各 5 分間観察した. 
T.C. $0.3 \mathrm{sec}$
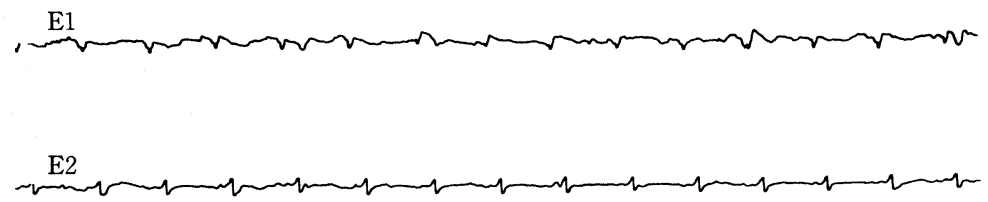

A E3
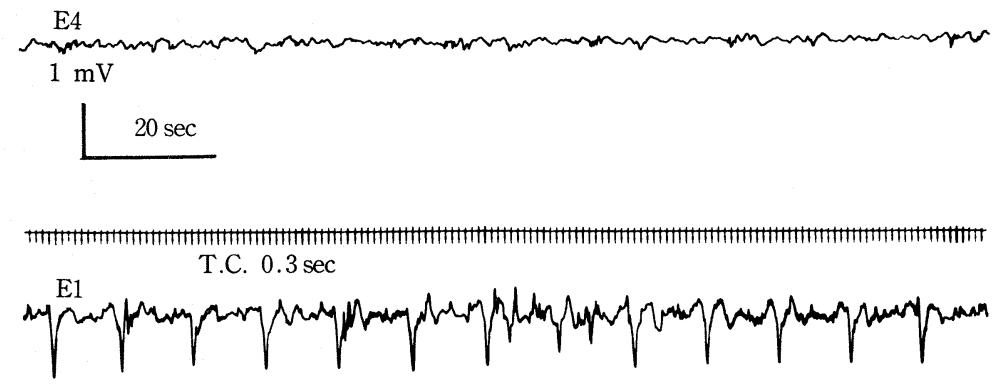

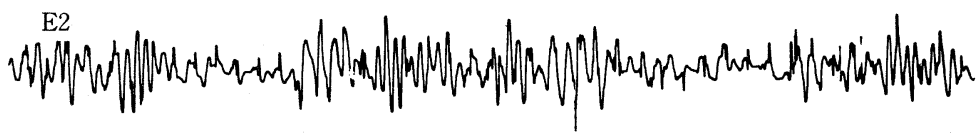

$\mathrm{B}$
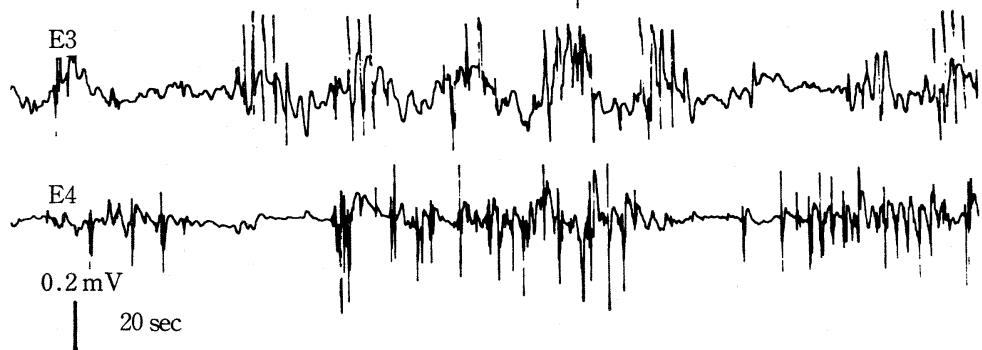

図 2. 空腹時および摂食後 5 分の大腸筋電図

A. 空腹時：近位大腸（E1，E2）に明膫な 5 cycles/min の slow wave がみられる. 遠位大腸 (E3,E4) では明らかではない.

B. 摂食後 5 分：各部位での電気活動が増強している. E1 では BER が規則正しく出現している が, これ以外は spike activity が出現し，BERは明らかではない。

薬物は tetragastrin, prostaglandin $\mathrm{F}_{2 \alpha}(\mathrm{PG}$ $\left.\mathrm{F}_{2 \alpha}\right)$, vagostigmineを使用し，投与は $1,3,4$, $5,10,15,20 \mu \mathrm{g} / \mathrm{kg}$ を 30 分間で静脈内に持続注 入した.

tetragastrin は胃十二指腸において basic electrical rhythm (BER) の発生頻度を增加させる 作用が観察されているが，近位大腸に打いては 一定した傾向はみられず，增量による明らかな dose response はなかった。
PG $\mathrm{F}_{2 \alpha}$ 投与前後の slow wave の 発生頻度に も明らかな変化は認められなかった.

vagostigmine 投与前後の slow wave の 発生 頻度は 5〜7 cycles/min の範囲にあり, 明らか な変化は認められなかった。

このように運動促進薬剤の静脈内投与ではslow wave は変化しなかったが spike activityは増強 した.とくに vagostigmine の静脈内投与は遠位 大腸に spike activity complex を確実に誘発し 


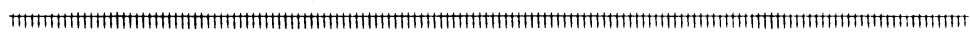

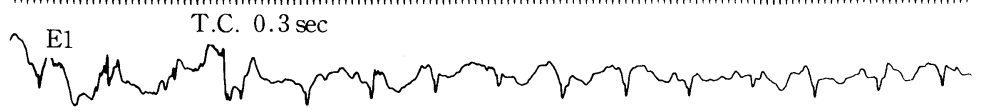

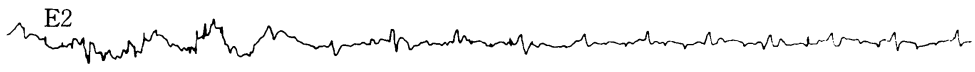

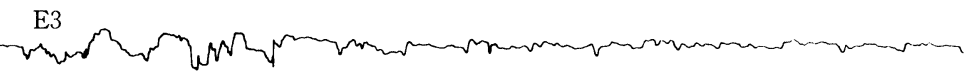

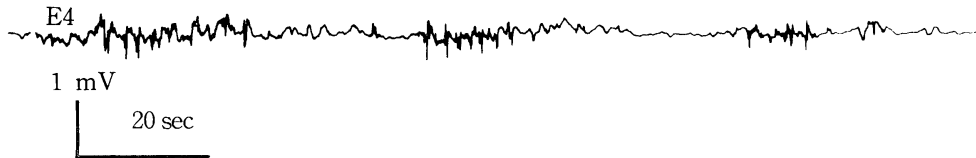

図 3. 排便後 15 分の大腸筋電図

直腸（E4）に spike activity complex がみられ，時間の経過とともに，その電位差が除々 に減衰している。
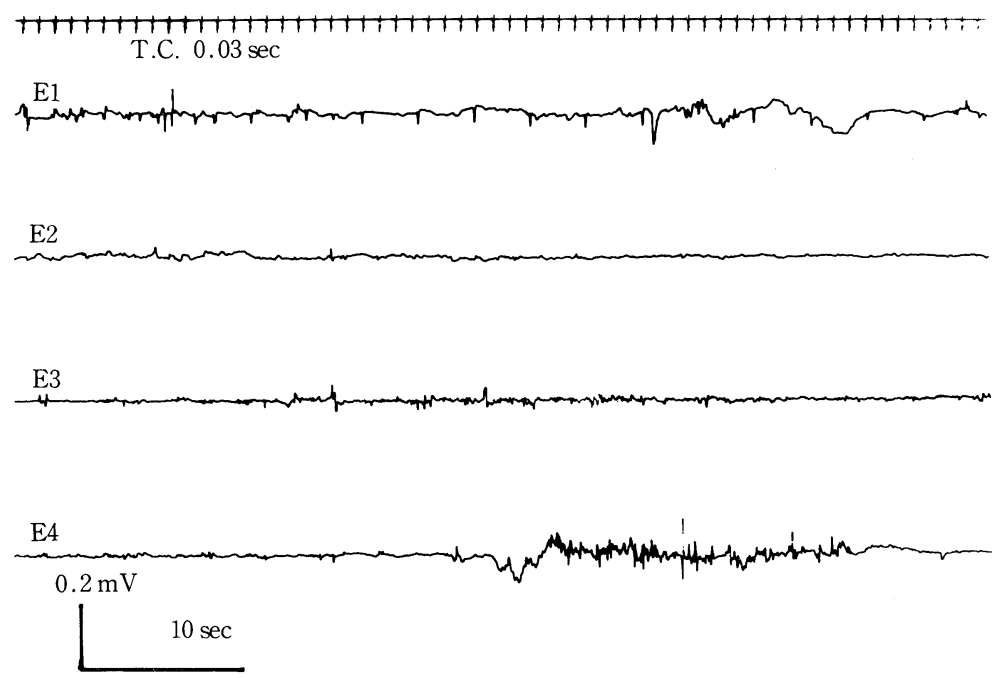

図 4. vagostigmine $0.5 \mathrm{mg}$ を静脈内に投与した後の大腸筋電図

直腸に spike activity complex が出現し，その時排便が認められた。

た（図 4)。この 事実をたしかめるため 開腹下に vagostigmine を投与し，大腸を肉眼的に観察す ると蠕動の充進が認められ，0.25〜0.5 mg の静 脈内投与で 5 分以内に 排便が誘発された. この spike activity は atropine $0.5 \mathrm{mg}$ の投与により 抑制された。

\section{24 時間記録による大腸筋電図の経時的変化}

記録紙の速度を $2 \mathrm{~mm} / \mathrm{min}$ とし 24 時間の連続
記録を行ない経時的变化を観察した。

spike activity および spike activity complex が集合してさらに大きい spike activity complex が形成されるのが認められた（図 5)。この spike activity complex が上行結腸から直腸に出現し, 上行結腸から直腸に伝播したごとくみられる場合 もあったが，大部分はそれぞれの関連は不定であ りその持続時間も一定していなかった. 摄食後に 


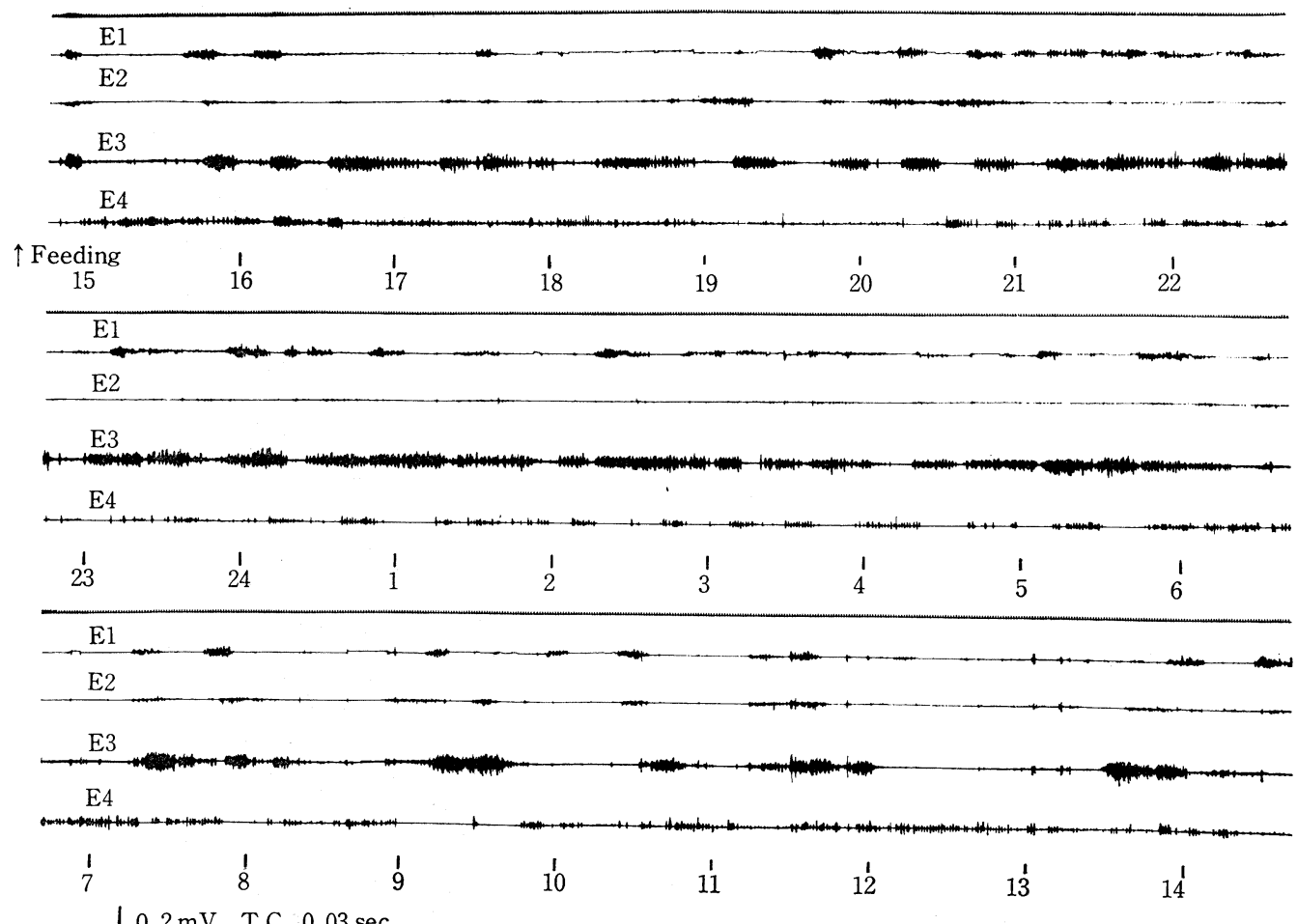

I $0.2 \mathrm{mV}$ T.C. $0.03 \mathrm{sec}$

図 5. 摂食後 24 時間の記録.

E1 から E4 に不規則に spike activity complexが認められる. 記録の最下段では spike activity complexが下方へ伝播しているようにみえる.

は spike activity complex は增強し, かつ不規 則に出現した。空腹時には spike activity complexの出現は減少し，摂食後に比較して規則的 であった．各部位での spike activity の出現頻 度をその 持続時間を測定し，24 時間中に 占める 割合として求めた。 3 頭のイヌについて各 3 回測 定した。 その平均は上行結腸 $46.9 \%$, 横行結腸 48.8\%, 下行結腸 $58.2 \%$, 直腸 $46.9 \%$ であっ た。

\section{D. 筋電図と機械曲線との対比}

上行結腸に $18 \sim 20 \mathrm{cycles} / \mathrm{min}$ で出現する spike activity がみられる時の機械曲線は一定し た周期をとらず，両者の完全な連関は認められな かった（図6-A）。をた slow wave が出現して いる時に機械曲線では収縮波が記録されたが，筋 電図との 1:1の連関はみられないことが多かっ た（図 6-B）。下行結腸において筋電図で約 1 分 間に 1 回出現する減衰型の spike activity が記 録されたが，機械曲線ではこれに連関して収縮波
がみられた。この 1 分間に 1 回規則正しく出現す る spike activity が連続してみられる時に機械 曲線ではこれに連関して基線の上昇を伴なって 1 分間に 1 回出現する 規則正しい収縮波が記録さ れ，10〜20 分間持続した（図 6-C，D）. 筋電図 で上行結腸および下行結腸に spike activity complex が出現する時にはこれに連関して収縮 波が記録された。この spike activity complex の持続時間は 10〜20 分であり，10〜30 分に 1 回 の周期で出現した。機械曲線ではこれに連関して 10〜30 分持続する収縮波が記録された。

\section{E. 低残濞食投与による大腸運動の変化}

イヌの飼育には 1 日に 1 回 固形食を投与した が, この状態での長時間の記録では通常各導出部 位にそれぞれ関連がないと思われる spike activity complex が別々に出現する場合が多くみら れた。この理由として大腸各部位の腸内容が異な ることが考えられたので, 大腸各部位の腸内容を 一定にするため低残渣食を用いた，投与法は 1 食 
A

E1

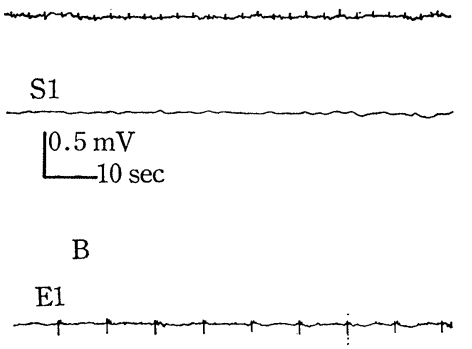

S1
C
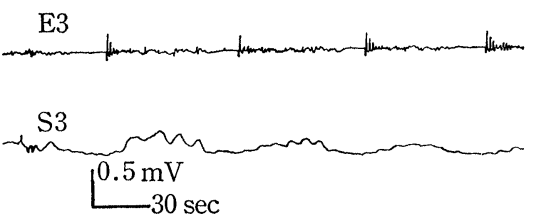

$\mathrm{D}$

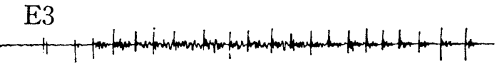

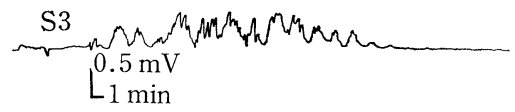

図 6. 筋電図と機械曲線の連関

$\mathrm{A} ： \mathrm{E} 1$ で 18〜20 cycles/min の電気活動がみられるが機械曲線ではこれに連関した収縮波はみられない。

B：E1で 5 cycles/min の電気活動がみられるが機械曲線にはこれに連関した収縮波はみられない。

C：E3で約 1 分間に 1 回 spike activity が出現し，機械曲線ではこれに連関して収縮波がみられる。

D：E3の spike activity complex 飞対して機械曲線に軽度の基線の上昇を伴なった収縮波がみられる。し かし図右側では電気活動に応じた収縮波は記録されていない。

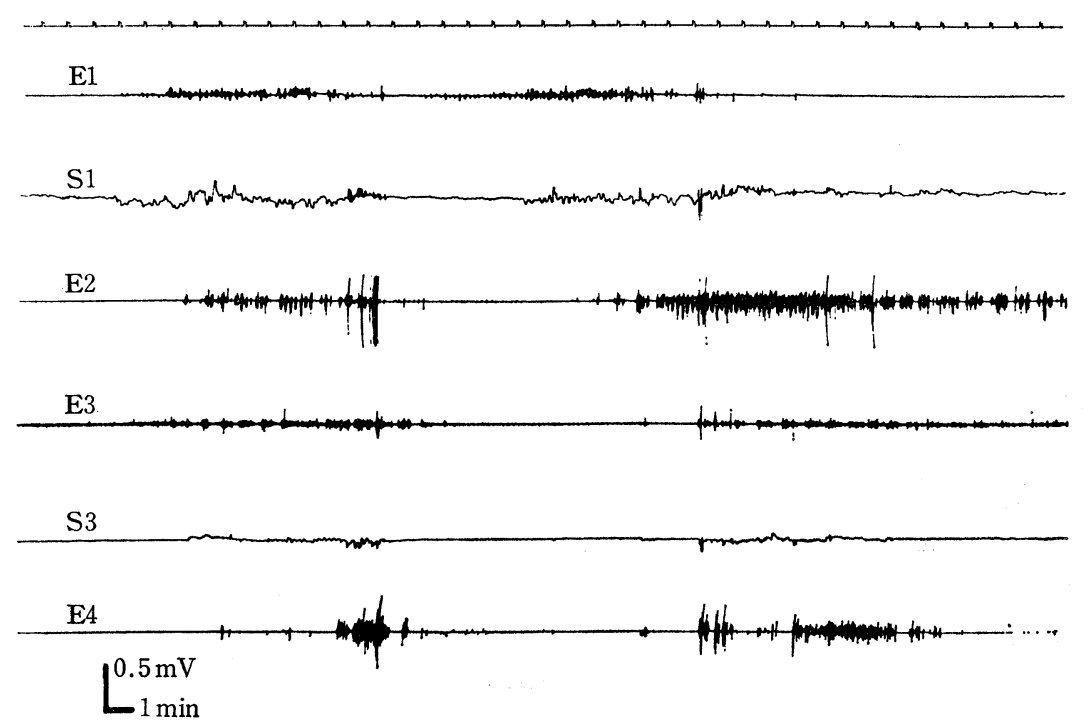

図 7. 低残渣食投与による bowel preparation 後の大腸各部位での筋電図と機械曲線

筋電図括よび機械曲線で運動が近位大腸から遠位大腸へ伝播したかのようにみ兄る。

$220 \mathrm{~g}$ を 1 日に 1 回, 1 週間以上連続投与した. このような bowel preparation の後に開復して 大腸を観察してみると大腸内には流動物がほぼ均 一に貯留していた，低残渣食投与後の筋電図およ び機械曲線の記録では投与前と比較して spike activity complex および contraction complex が上行結腸より直腸へ伝播したごとくみられる場
合が多く，静止期が投与前より明らかであった (図 7).

各導出部位での 低残渣食投与前後での spike activity complex と収縮波の持続時間が 24 時 間中に占める割合を比較した. spike activity complex は下行結腸において持続時間が長い傾 向があり, 投与前後とも同樣の傾向があった（図 


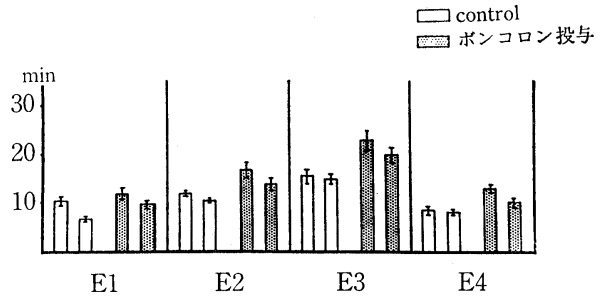

図 8. 各導出部位の spike activity complex の 持続 時間

ボソコロソ投与前後, 各 2 回の 24 時間連続記 録での比較. 下行結腸で spike activity complex の持続時間が長い.

8)。また spike activity complex の 24 時間中に 占める割合は投与前後とも下行結腸に高く, かつ 投与後にやや増加した（図 9). 収縮波の持続時

\section{IV. 考}

著者は意識下において大腸筋電図の記録を行な ったが，大腸筋電図所見は胃や小腸のそれに比較 して非常に多様であり, slow wave, spike およ び spike burst が認められ，これらが単独で出現 したり，同時に出現する事もありまた各型の移 行型もみられた．著者は大腸の電気活動を slow wave, spike activity, spike activity complex の 3 型に分け, 分析を行なった. 意識下の記録で は spike activity complex が多く出現して, こ れが電位の低い slow wave の識別を困難にし た.ラボナール麻酔下においては spike activity は減少し, slow wave が比較的多く出現した。 spike activity が減少するのは麻酔下では腸管運 動が抑制されるためだと思われる。

slow wave の出現頻度は諸家によりさまざま で, Taylorら (1974) はヒトの安静時の記録で直 腸と $\mathrm{S}$ 字状結腸に $2.5 \sim 4.0 \mathrm{cycles} / \mathrm{min}$ と $6 \sim 9$ cycles/min の slow wave を認め, $2.5 \sim 4.0$ cycles/min の slow wave は pentagastrin で増 加し, 6〜9 cycles/min の slow wave は neostigmine で増加したと報告した. Snape ら (1977) はヒトの直腸と $\mathrm{S}$ 字状結腸の記録で, slow wave は 49土3.0\%の出現率で $3.5 \pm 0.1$ cycles $/ \mathrm{min}$ と $6.5 \pm 0.1$ cycles/min の 2 つの slow wave を導 出できたとし，薬物投与により spike potential activity は増強したが, slow waveの activity

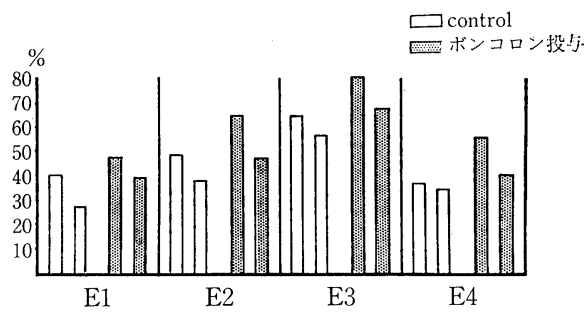

図 9. 各導出部位の spike activity complex の 24 時 間に占める割合 ボンコロン投与前後とも下行結腸に spike activity comlexの 24 時間に占める割合が多い.

間及び 24 時間中に占める割合は上行結腸と下行 結腸に大差はみられず，また投与前後でも明らか な差はなかった。

\section{察}

と frequency は变化せず, また食物の投与量に よってもこれらは变化しなかったと報告してい る. Capirilli(1975) はイヌの記録で 5.46 cycles/ min と 18.53 cycles/min の slow waveを導出 し, 前者は右側大腸に多く, 後者は中央から左側 大腸に多く出現したとのべている，著者の記録で は slow wave は遠位大腸よりも近位大腸に多く 導出され，5〜6 cycles/min の周波数が多かった. 摂食後には spike activity は増強したが slow wave の frequency の変化は少なく，また薬物刺 激に执いても明らかな变化はみられなかった。 slow wave とは別に 17〜18 cycles/min の spike activity が単独で出現する場合，あるいは slow wave と同時に出現する場合もみられた。

spike activity complex は遠位大腸とくに直 腸に多く, 約 1 分間に 1 回出現し, 持続時間は経 時的に変動した。摂食後には spike activity complex は増強して持続時間は延長し, 休止時 間も延長した。ラボナール麻酔下では持続時間は 軽度延長するが，休止時間は $40.2 \pm 19.4$ 秒で空 腹時の $28.8 \pm 11.7$ 秒に比べ延長しておうう，その 出現頻度は減少していた。 vagostigmine 投与に より消化管運動を充進させると spike activity complex は増強し, atropine 投与により抑制さ れた。排便時には直腸に spike activity complex が出現し、時間とともに減衰した。 spike activity 
complex は大腸の運動尣進時に出現し, 排便時に 直腸にみられることより大腸の内容輸送に関係し ていると考えられる。

大腸運動をバルーンを用いて内压曲線により観 察したものはこれまでにも報告は多く, strain gauge を消化管に植込み機械曲線を観察した報告 も多い。しかし機械曲線と筋電図を同時に記録し て比較した報告は少ない。尼川（1974）はイヌを 用いて下行結腸に strain gauge と銀針双極電極 を植込み麻酔下での記録を行ない機械曲線上 $3 つ$ の波型にわけ，筋電図での spike burst の周期 が 11〜16 秒のものが多く, 収縮時間が短い波型 と一致することが多いとのべた，著者の記録で は, 機械曲線では約 1 分間に 1 回出現する収縮波 と，これが 10〜30 分間持続する収縮波がみられ た。筋電図での slow wave および 18〜20 cycles/ min の spike activity と機械曲線とは 1:1の連 関がみられないことが多かったが，1 分間に 1 回

\section{ま と}

イヌを用いて大腸筇電図と機械曲線を導出し, 大腸運動を分析した。

slow wave は 5〜 6 cycles/min の周期で近位 大腸に多く出現し, 薬物刺激で明らかな変化はみ られなかった。

spike activity complex は遠位大腸に多く出現 し, 排便時, vagostigmine 投与後など運動充進 時に出現した。また 24 時間連続記録では下行結 腸に多く導出された.

機械曲線では 1 分間に 1 回出現する収縮波と, これが 10〜30 分間持続する contraction com-
出現する spike activity とは 1:1の連関がみら れた. spike activity complex と収縮波とはよ く連関がみられ, spike activity complex が大腸 の収縮運動時に出現すると考えられる.

24 時間の連続記録を行ならことにより経時的 変化をみると, spike activity complex は上行 結腸から直腸の導出に認められたが, 各部位に独 立して出現し，それぞれの関連は認められなかっ た.これは大腸各部位での内容量が異なるためだ と考光られる。内容量を一定にするため, 低残渣 食を投与して観察したところ, spike activity complex が上行結腸より直腸に伝播したごとく みられる場合が多かった．腸内容が大腸に一様に 存在する場合収縮運動が近位より遠位に伝播する ことが多いが，これとは逆に大腸各部位が独自の 収縮運動をしていることもあり,この複雑な運動 形式は大腸の粪便の形成, 貯留の機能に関連して いると考号れ興味深い。

\section{ぬ め}

plexが記録された。これらは spike activity complex よよく連関した。

低残渣食投与後は投与前と比較して spike activity complex と収縮波が上行結腸から直腸 へ伝播したごとくみえる場合が多かった.

本論文の要旨を第 20 回，第 21 回日本平滑筋学会総会， 第 178 回徳島医学会で報告した.

稿を終るにあたりご校閲とご指導を賜わりました古味信 彦教授, 桑島輝夫助教授, 蔵本守雄講師に心から謝意を表 します。

\section{文献}

尼川紘史 (1974)。下行結腸及び直腸に抢ける内容輸送と排便運動の基礎的研究. 広島医学雑誌 22：327-361.

Atkinson, A.J., Adler, H.F. and Ivy, A.C. (1943). Motility of the human colon. J.A.M.A. 121: 646-652.

Bass, P. and Wiley, J.N. (1972). Contractile force transducer for recording muscle activity in unanesthetized animals. J. Appl. Physiol. 32: 567-570.

本田徤三朗 $(1960)$ ． 消化管の働作電流及び内圧の変化についての実験的研究. 日本外科宝函 29: 527-535.

伊藤 漸 (1974). Extraluminal strain gage force transducer の作製と慢性植込. 日平滑筋誌 13: 33-43.

Jacoby, H.I., Bass, P. and Benneff, D. (1963). In vivo extraluminal contractile force transducer for gastrointestinal muscle. J. Appl. Physiol. 18: 658-665.

喜多孝志ら (1978). イヌ大腸運動の筋電図学的観察. 日平滑筋誌 14：324-325.

喜多孝志ら (1979). イヌ大腸運動について. 日平滑筋誌 15：178-179.

桑島輝夫ら (1975). 植込み双極電極導出法による消化管笳電図および電極作製方法と没埋方法. 日平滑筋誌 11: 21-27. 
Reinke, D.A., Rosenbaum, A.H. and Benneff, D.R. (1967). Patterns of dog gastrointestinal contractile activity monitored in vivo with extraluminal force transducers. Amer. Jour. of Digest. Dis. 12: 113-141.

Snape, W. J., Carlson, G.M. and Cohen, S. (1977). Human colonic myoelectric activity in response to prostigmin and the gastrointestinal hormones. Digestive Diseases 22: 881-887.

Snape, W. J., Mantarazzo, S.A. and Cohen, S. (1978). Effect of eating and gastrointestinal hormones on human colonic myoelectrical and motor activity. Gastroenterology 75: 372-378.

鈴木三郎 (1958). 腸運動の動作電流. 日外会誌 59：1-3.

Taylor, I. et al. (1974). The effecr of stimulation on the myoelectrical activity of the rectosigmoid in man. Gut 15: 599-607.

高木紘一ら (1973)。SA-504 の大腸筋電図. 日平滑筋誌 9: 147-150.

Templeton, R.D. and Lawson, H. (1931). Studies in tie motor activity of the large intestine. Am. J. Physiol. 96: 667-676.

植田 隆, 鈴木三郎 (1956). 人腸管の働作流とその臨床応用について. 日外会誌 57：605-610.

Vanasin, B., Ustach, T.J. and Schuster, M.M. (19/1). Elestrical and motor activity of human and dog colon in vitro. Hopkins Med. J. 134: 201-210.

(1980 年 9 月 17 日受付) 